\title{
Control of separately excited DC motor with series multi-cells chopper using PI - Petri nets controller
}

https://doi.org/10.1515/nleng-2017-0174

Received November 1, 2017; revised January 23, 2018; accepted March 17, 2018.

Abstract: The separately excited Direct Current (DC) motor is widely used in many industrial sectors. During the operation of the DC motor, the load torque and the voltage of the network can cause a destabilization of the actual speed and actual current. Thus, the need to regulate the speed and current of the DC motor is a very important research problem. In this paper, a control strategy of separately excited DC motor using a series multicells chopper is described. The proposed control is based on Proportional-Integral (PI) and Petri nets controllers. Specifically, the conventional PI controller is used to control the speed of DC motor. The Petri nets controller ensures the regulation of the armature current and to maintain the capacitor voltage of the multi-cells converter to its reference. The Petri nets controller also generates binary control switches. The proposed control system has been implemented using MATLAB Sim Power. Simulation results demonstrate that a series multi-cells chopper and the proposed control give a good performance and high robustness in load disturbance for the separately excited DC motor.

Keywords: Separately excited DC motor; series multi-cells chopper; PI controller; Petri nets controller; hysteresis methodology

\section{Introduction}

Many industrial sectors such as robotics, steel rolling mills, electric cranes, and grinding, electrical vehicles use the DC motor [1-6]. Some important advantages in using the DC motor can be listed as follows:

\footnotetext{
Mohamed Lamine Hamida, Hakim Denoun, Arezki Fekik, Laboratory of Research, LATAGE, Mouloud Mammeri University, Algeria, E-mail:ml_hamida@yahoo.com, akim_danoun2002dz@yahoo.fr, arezkitdk@yahoo.fr

Sundarapandian Vaidyanathan, Research and Development Centre, VelTech University, India, E-mail: sundarvtu@gmail.com
}

1. A DC motor is controllable for a wide range and it can be easily used for constant torque and speed.

2. A DC motor can be rapidly accelerated or decelerated, and can respond to feedback control, low cost and less complex control structure.

There are several ways to vary the speed of the DC motor such as field flux control and rheostatic armature control. The rheostatic armature control method is just used in the case of low power. The speed of the DC motor can also be varied by varying the armature voltage. In this case, a portion of the energy is consumed by the feeding device. For this reason, it is preferable to feed the DC motor discontinuously with a controlled rectifier or with a buck chopper. The traditional buck chopper is used in many works as in [7-12].

In this work, a series multi-cells chopper structure is used to control the separately excited DC motor. The series multi-cells chopper structure is based on the series association of elementary switching cells [13-16]. This structure, which appeared at the beginning of the 1990s, allows the sharing of voltage constraints by all commutation series connected cells and flying capacitors, where the flying capacitor voltages determine the output waveform quality and the safe converter operation. The multi-cells converter is used in different applications such as harmonics filtering, renewable energy systems, and voltage dynamic restoration.

During the operation of the DC motor, the load torque and the voltage of the network can cause a destabilization of the actual speed and actual current, which is not desired. Thus, it is important to regulate the speed and the current of the DC motor. The regulation works on two sides: (i) on the speed of the DC motor and (ii) the armature current to keep it within acceptable limits in the situations such as rapid start, sudden change in the resistive torque, sudden braking or very rapid increase in the set point of the speed.

The structure of the DC motor controller of the speed generally consists of two loops. The first loop compares the actual speed with the speed reference, and the second loop controls the armature current. 
Proportional-Integral (PI) controller is often to control the motor speed of the DC motor. The major features of the PI controller are its simplicity and ability to maintain a zero steady-state error to a step change in reference. Instead of using another PI or hysteresis controller to regulate the armature current as used in [4-6, 17-20], we propose the use of the Petri nets controller.

The role of the Petri nets controller is to achieve both the armature current tracking and a good balance of the capacitor voltage of 2-cells chopper with respect to the tolerance errors of armature current and capacitor voltage .The outputs of the Petri nets controller generate binary control switches which boot up the IGBTs of the two cells chopper. A control based on Petri nets is proposed in [26] to control a three multi-cells chopper connected to R, L load. The experimental results have shown the performance of the proposed controller.

The Petri nets controller minimizes the number of the commutations compared to the PWM control (see [2126]).It is important to improve the content of the output energy and the efficiency of the system by the reduction of the switching losses.

This paper is organized as follow: The modeling of separately excited DC motor is presented in Section 2.The modeling of the driving system based on series multi-cells chopper is given in Section 3.The proposed control strategy is presented in Section 4. The simulation results are tested and analyzed in Section 5. Finally, a conclusion is drawn in Section 6.

\section{Modeling of Separately Excited DC Motor}

The separately excited DC motor has two windings and each one of them is powered by a separate power supply voltage. Figure 1 shows the equivalent circuit of separately excited motor, where $R_{a}$ and $L_{a}$ represent the resistance and the inductance of the armature winding, respectively. The resistance and the inductance of the field winding are denoted by $R_{f}$ and $L_{f}$, respectively. Also, $E_{a}$ is the emf induced in the armature circuit, $\omega$ the motor speed, $k_{b}$ is the back emf constant, $T_{e}, T_{L}$ are the motor and the load torque, respectively, $B$ is the viscous friction coefficient and $J$ is the total inertia of motor.

The mathematical model of the DC motor consists of electrical and mechanical equations. These two groups of equations allow us to understand better the DC motor in its real operation. This model is governed by the following
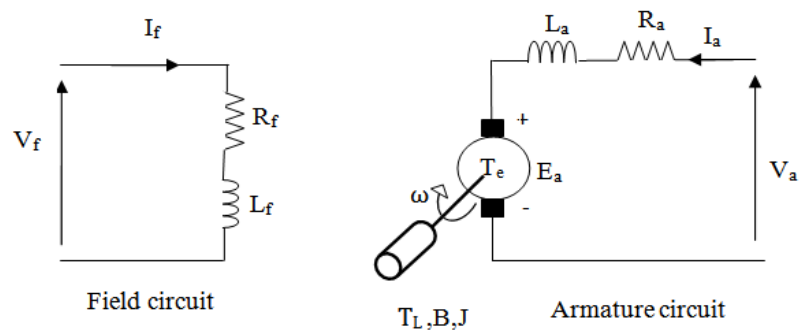

Fig. 1: Separately excited DC motor

equations:

$$
\begin{gathered}
V_{a}(t)=R_{a} I_{a}(t)+L_{a} \frac{d I_{a}(t)}{d t}+E_{a}(t) \\
V_{f}(t)=R_{f} I_{f}(t)+L_{f} \frac{d I_{f}(t)}{d t} \\
E_{a}(t)=k_{b} \omega(t) \\
T_{e}=J \frac{d \omega(t)}{d t}+B \omega(t)+T_{L}
\end{gathered}
$$

\section{Series Multi-cells Chopper Model}

Figure 2 represents a $p$-cells chopper connected to the DC motor. It is based on the association of $p$ commutation cells where each one is composed of pairs of complementary switches [27]. We insert flying capacitors between these complimentary switches later. Each cell is controlled by a binary function $u_{k}(t) \in\{0,1\}, k=1,2, \ldots, n$, where $u_{k}=1$ indicates that the upper switch is closed, and thelower switch is open.

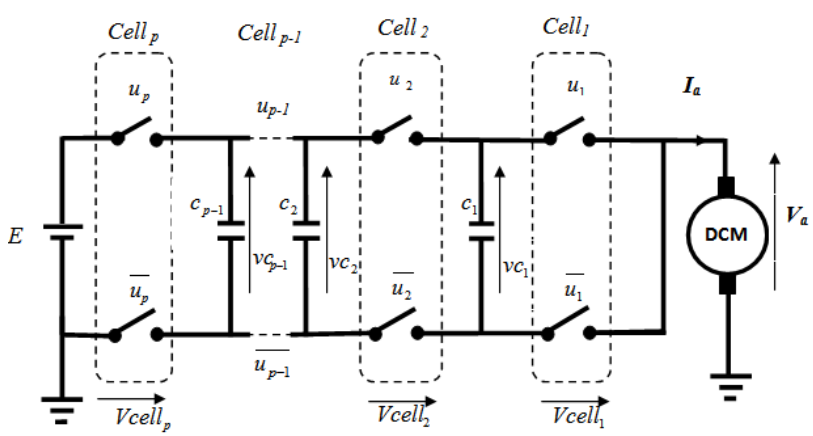

Fig. 2: $p$-cells chopper structure

The instantaneous model of a multicellular chopper with a $p$-cells connected to DC motor is described by the 
system of equations (5).

$$
\left\{\begin{array}{l}
\frac{d V_{C 1}}{d t}=\frac{u_{2}-u_{1}}{C_{1}} I_{a} \\
\frac{d V_{C 2}}{d t}=\frac{u_{3}-u_{2}}{C_{2}} I_{a} \\
\vdots \quad \vdots \\
\frac{d V_{C p-1}}{d t}=\frac{u_{p}-u_{p-1}}{C_{p-1}} I_{a} \\
\frac{d I_{a}}{d t}=\frac{u_{2}-u_{1}}{L_{a}} V_{C 1}+\ldots+\frac{u_{p}-u_{p-1}}{L_{a}} V_{c p-1}+\frac{u_{p}}{L_{a}} E \\
\quad-\frac{R_{a}}{L_{a}} I_{a}-\frac{k_{b} \omega}{L_{a}}
\end{array}\right.
$$

where

$$
\begin{gathered}
V_{a}=\sum_{k=1}^{p} u_{k} V_{\text {cell }_{\mathrm{k}}} \\
V_{\text {cell }_{\mathrm{k}}}=V_{c_{k}}-V_{c_{k}-1}
\end{gathered}
$$

In our application, the two cells chopper is used. Thus, the system (5) becomes:

$$
\left\{\begin{array}{l}
\frac{d V_{C 1}}{d t}=\frac{u_{2}-u_{1}}{C_{1}} I_{a} \\
\frac{d I_{a}}{d t}=\frac{u_{2}-u_{1}}{L_{a}} V_{C 1}+\frac{u_{2}}{L_{a}} E-\frac{R_{a}}{L_{a}} I_{a}-\frac{k_{b} \omega}{L_{a}}
\end{array}\right.
$$

In Eq. (8), $V_{c 1}$ is the capacitor voltage, and $u_{1}, u_{2}$ are the binary switches.

To ensure normal operations, it is necessary to guarantee a balanced distribution of the floating voltages, i.e. $V_{c k}=\frac{k E}{p},\left(V_{c l}=\frac{E}{2}\right.$ for 2 cells chopper $)$.

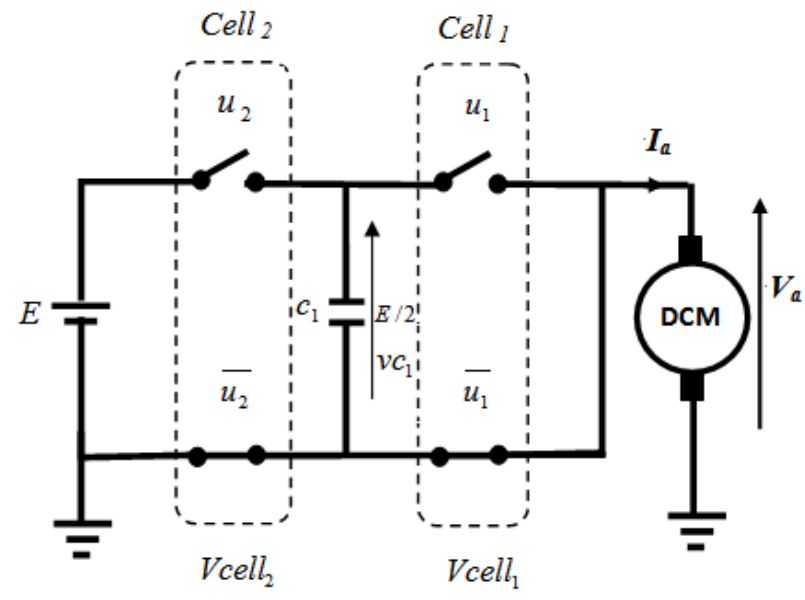

Fig. 3: Two cells chopper connected to DC motor

The hybrid model of the two cells chopper is given as follows.

$$
\begin{aligned}
& \dot{X}=A(u) X+B(u) E \\
& Y=C I_{a}
\end{aligned}
$$

Table 1: Operating modes of the 2-cells chopper

\begin{tabular}{llll}
\hline$u_{2}$ & $u_{1}$ & $V_{C_{1}}$ & $V_{a}$ \\
\hline 0 & 0 & 0 & 0 \\
0 & 1 & $-V_{C_{1}}$ & $E / 2$ \\
1 & 0 & $V_{C_{1}}$ & $E / 2$ \\
1 & 1 & 0 & $E$ \\
\hline
\end{tabular}

where

$$
X=\left[\begin{array}{c}
I_{a} \\
V_{C_{1}}
\end{array}\right],
$$

$$
\begin{gathered}
A=\left[\begin{array}{cc}
0 & \frac{u_{2}-u_{1}}{C_{1}} \\
\frac{u_{2}-u_{1}}{L_{a}} & -\frac{R_{a}}{L_{a}}
\end{array}\right], \\
B=\left[\begin{array}{cc}
0 \\
\frac{E}{L_{a}} u_{2}-\frac{k_{b} \omega}{L_{a}}
\end{array}\right],
\end{gathered}
$$

$$
C=\left[\begin{array}{ll}
0 & 1
\end{array}\right]
$$

Also, $u$ is the vector of interconnection

$$
u=\left[\begin{array}{l}
u_{1} \\
u_{2}
\end{array}\right]
$$

Table 1 represents the different configurations of the two cells chopper, depending on the position of switches. In this case, we have $2^{2}=4$ discrete modes.

\section{Control Strategy}

The control model scheme of a PI - Petri nets controller of the separately excited DC motor is shown in Figure 4.The control scheme consists of two parts: (i) a continuous part and (ii) a discrete part. The first part is based on the PI controller. The inputs of the PI controller are the reference speed and the actual speed. The output is the armature current reference, which is compared with actual armature current. The second part is based on the Petri nets controller to regulate the armature current and the capacitor voltage. The control strategy consists to regulate the capacitor voltage $V_{C_{1}}$ to the reference value $V_{C_{1} \text { ref }}$ and to regulate the armature $I_{a}$ current to the reference value $I_{a \text { ref }}$.

To ensure this regulation, a hysteresis methodology is used $[25,26]$.

An operating band (tolerance errors) is provided such that the load current and capacitor voltage rest inside:

$I_{\text {aref }}-\delta_{1} \leq I_{a} \leq I_{\text {aref }}+\delta_{1}$ and $V_{C_{1} \text { ref }}-\delta_{2} \leq V_{C_{1}} \leq$ $V_{C_{1} \text { ref }}+\delta_{2}$ 


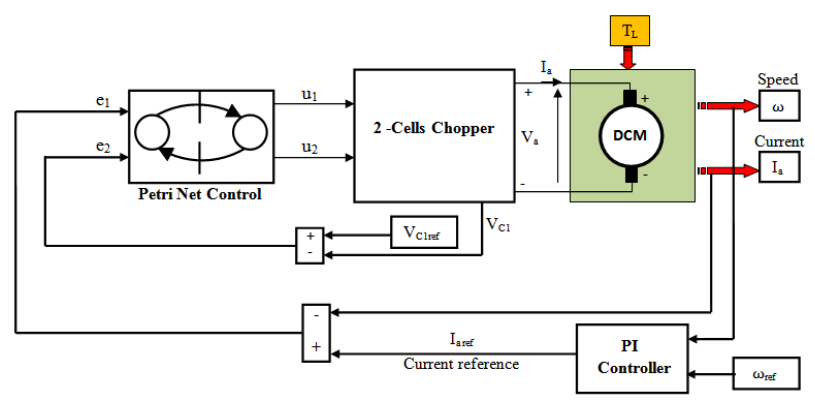

Fig. 4: Design of PI-Petri nets Controller for a SEDCM

Table 2: Signification of Places

\begin{tabular}{ll}
\hline Places & Designations \\
\hline $\mathrm{P}_{0}$ & The initial state of the commutation switches \\
$\mathrm{P}_{1}$ & The state of the switch of the first cell \\
$\mathrm{P}_{2}$ & The state of the switch of the second cell \\
\hline
\end{tabular}

where $\delta_{1}$ and $\delta_{2}$ are the tolerance errors of load current and capacitor voltage, respectively. The states of the binary switches of cell $l_{1}$ and cell $l_{2}$ are denoted by $u_{1}, u_{2}$, respectively, which are modeled by the two places $P_{1}$ and $P_{2}$ (Figure 5).The converter is allowed to configure by two possible configurations. In the first configuration, only one switch is allowed to be passing. In the second configuration, two switches are allowed to be passing.

The significance of all places and transitions are shown in Table 2.The closure of the switch of the cell (Celli) depends on the validation of the transition $t_{i 0}$ and the elapsed delay $d_{i}, i=1,2\left(d_{1}\right.$ of $P_{1}$ for the switching Cell ${ }_{1}$ and $d_{2}$ of $P_{2}$ for the switching Cell $_{2}$ ). It is noted that the time allowed between two successive commutations is modeled by the delay $d_{i}$. In this work, the delays of $P_{1}$ and $P_{2}$ places are considered as the same $\left(d_{1}=d_{2}=2 E-5 s\right)$. Finally, the presence of two arcs inhibitors in the proposed Petri net control leads to prevent the presence of more than one token in places $P_{1}$ and $P_{2}$.

Transitions from one place to another depend on the admissible errors of output current andcapacitor voltage as shown in Table 3.

In Table $3, \delta_{1}$ is the load current tolerance error and $\delta_{2}$ is the capacitor voltage tolerance error. After many tests to

Table 3: Transitions

\begin{tabular}{ll}
\hline Transitions & Designations \\
\hline $\mathrm{T}_{01}$ & $\left(e_{1} \geq \delta_{1}\right.$ or $\left.-\delta_{1}<e_{1}<\delta_{1}\right)$ and $e_{2}<-\delta_{2}$ \\
$\mathrm{~T}_{02}$ & $\left(e_{1} \geq \delta_{1}\right.$ or $\left.-\delta_{1}<e_{1}<\delta_{1}\right)$ and $e_{2}>\delta_{2}$ \\
$\mathrm{~T}_{10}$ & $\left(e_{1} \leq-\delta_{1}\right.$ or $\left.-\delta_{1}<e_{1}<\delta_{1}\right)$ and $e_{2}>\delta_{2}$ \\
$\mathrm{~T}_{20}$ & $\left(e_{1} \leq-\delta_{1}\right.$ or and $e_{2}<-\delta_{2}$ \\
\hline
\end{tabular}

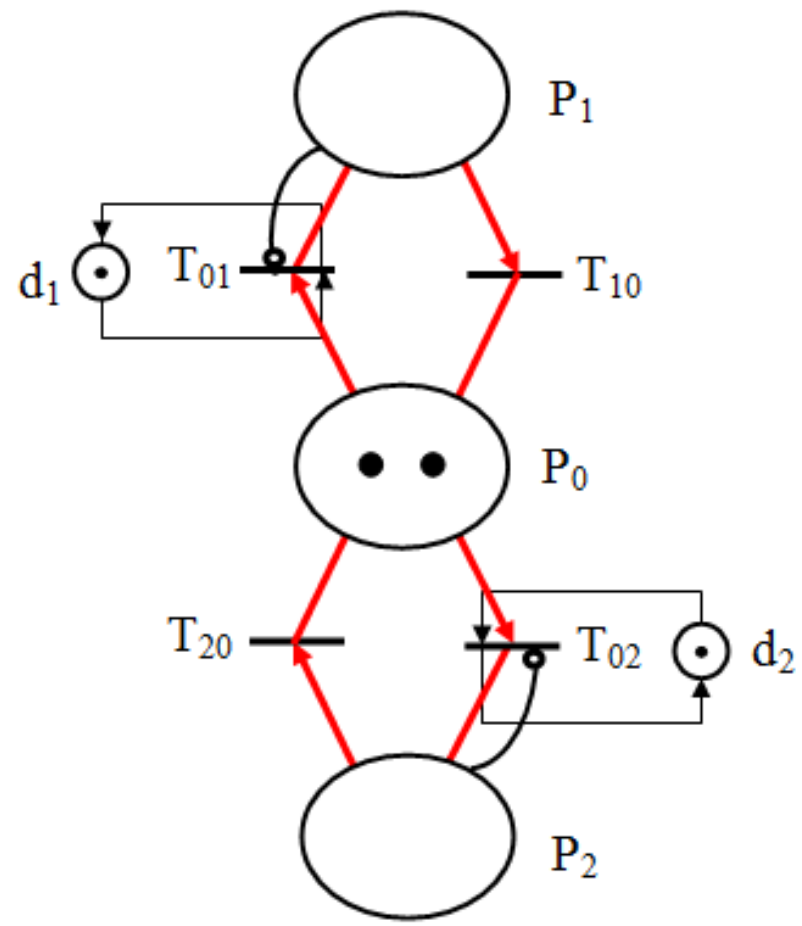

Fig. 5: Petri net graph for a control switches of 2-cells chopper

define the safe values of the load current and the capacitor voltage tolerance errors, we found that for the values of $\delta_{1}$ and $\delta_{2}$ chosen as $\delta_{1}=0.01 \mathrm{~A}$ and $\delta_{2}=0.2 \mathrm{~V}$ we get the optimum functioning of our system.

For the two cells chopper, four transitions are possible. For example, the $\mathrm{T}_{01}$ transition is firing if the armature current error is superior or equal to the positive tolerance of the output current, i.e. $e_{1} \geq \delta_{1}$. In this case, the current must increase. Thus, the $u_{1}$ switch is committed to open and hence $T_{01}=1$. If the armature current is inside the hysteresis band, i.e. the $\mathrm{T}_{01}$ transitionis depending on the capacitor voltage. If the capacitor voltage is less than the negative tolerance error of the voltage capacitor, i.e. the capacitor should be unloaded, and the transition $\mathrm{T}_{01}$ is reached.

\section{Simulations and Results}

The parameters used in this work are the parameters of the available separately excited DC motor in the LATAGE laboratory. After carrying out several tests of identification of the parameters, the Separately excited DC motor and multicellular chopper characteristics are given in Table 4. 
Table 4: The separately excited DC motor and the two cells chopper parameters

\begin{tabular}{ll}
\hline Nominal motor speed $\omega$ & $157 \mathrm{rad} / \mathrm{s}$ \\
Power & $3 \mathrm{Kw}$ \\
Nominal armature voltage $\mathrm{V}_{a}$ & $300 \mathrm{~V}$ \\
Nominal Field voltage $\mathrm{V}_{f}$ & $110 \mathrm{~V}$ \\
Armature resistance $\mathrm{R}_{a}$ & $1.35 \Omega$ \\
Field resistance $\mathrm{R}_{f}$ & $65,15 \Omega$ \\
Armature inductance $\mathrm{L}_{a}$ & $0.0059 \mathrm{H}$ \\
Field inductance $\mathrm{L}_{f}$ & $8.35 \mathrm{H}$ \\
Field-armature mutual inductance & $1.07 \mathrm{H}$ \\
Back Emf constant $\mathrm{k}_{b}$ & $1.41 \mathrm{~V} / \mathrm{rd} / \mathrm{s}$ \\
Viscous friction coefficient B & $0.0045 \mathrm{~N} . \mathrm{m} . \mathrm{s}$ \\
Total inertia J & $0.036 \mathrm{~kg} . \mathrm{m}^{\wedge} 2$ \\
Capacitance $\mathrm{C}_{1}$ & $33 \mu \mathrm{F}$ \\
Voltage source $\mathrm{E}$ & $300 \mathrm{~V}$ \\
$\mathrm{~V}_{C 1 \text { ref }}=\mathrm{E} / 2$ & $150 \mathrm{~V}$ \\
\hline
\end{tabular}

The PI-Petri Nets controller was simulated using Matlab-Simpower System software and the speed controller of the separately excited motor was successfully tested. Three performance testing are made as follows:

Test 1: The reference speed is set as $\omega_{\text {ref }}=157 \mathrm{rad} / \mathrm{s}$ with no load conditions. Figures 7 and 8 show the simulation results of the motor speed and the armature current.

Test 2: The reference speed change according to the protocol shown in Figure 6 with the load conditions ( $5 \mathrm{Nm}$ ). Figures 9 and 10 show the corresponding simulation results. Test 3: The load torque change at $\mathrm{t}=2.5 \mathrm{~s}$ from $5 \mathrm{Nm}$ to $15 \mathrm{Nm}$ and the corresponding simulation results are shown in Figures 11 and 12.

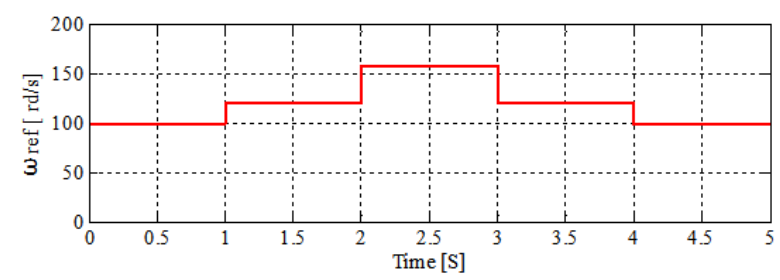

Fig. 6: Protocol of speed reference

The simulation results confirm that using the multicellular chopper in the proposed control scheme gives good results in the closed-loop control scheme. It is clear that the proposed PI-Petri nets controller permits to regulate the motor speed to its reference in a short time. The Petri nets controller shows a good tracking of armature current in a short time and is perfectly maintained between the desired bands. It also showed that the floating voltage reach its desired value in a short time and is well balanced

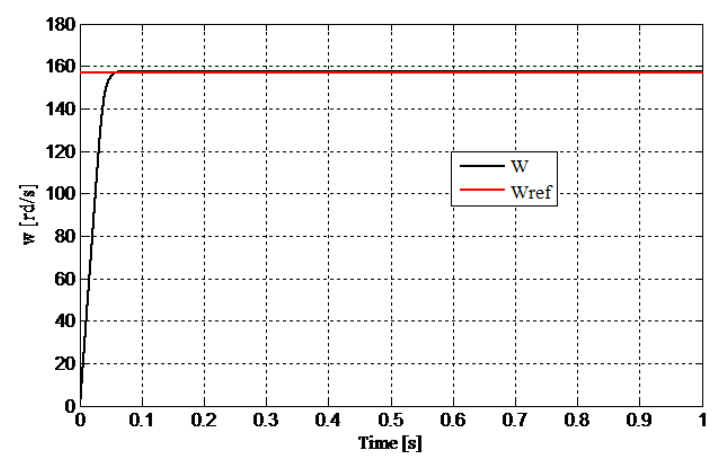

Fig. 7: Rotor speed of the motor and its reference

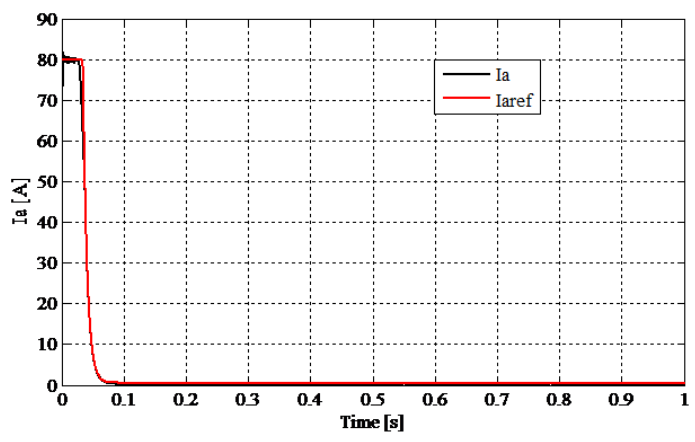

Fig. 8: Armature current and its reference

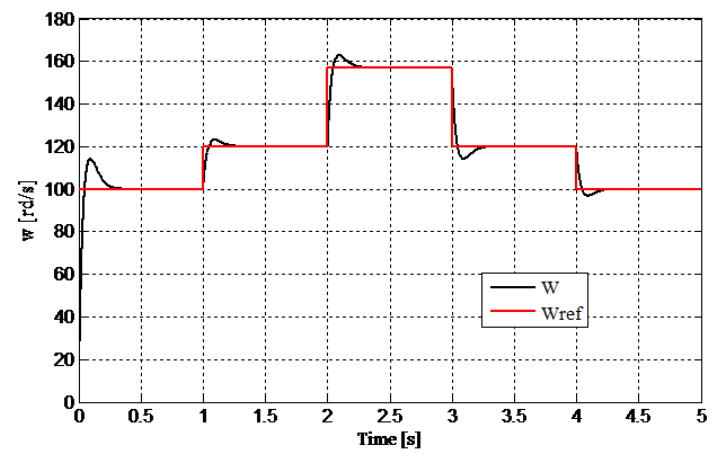

Fig. 9: Rotor speed of the motor (variation of the speed reference)

around the reference value (Figure 13) with respect to the predefined tolerance error.

\section{Conclusion}

The PI-Petri nets controller proposed in this paper regulates successfully the speed and the armature current of the separately excited DC motor. We use the multi-cells chopper converter to feed the separately excited DC motor, and the combination of the PI and Petri nets controllers. 


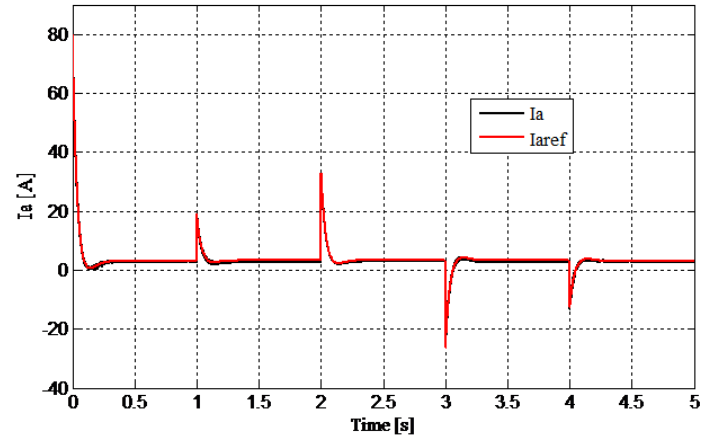

Fig. 10: Armature current and its reference (variation of the speed reference)

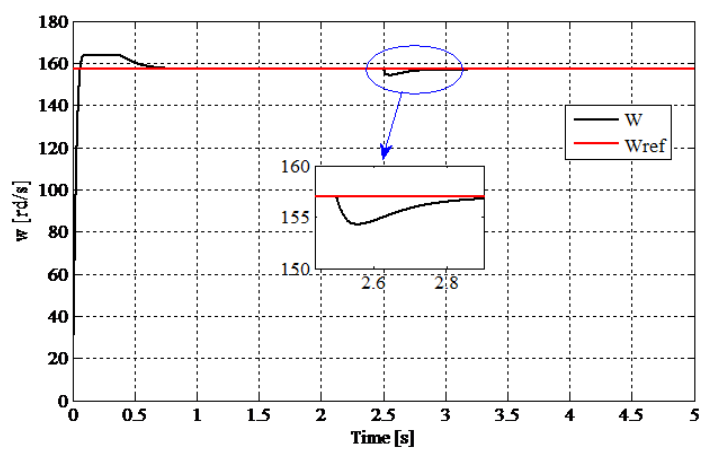

Fig. 11: Rotor speed of the motor (speed reference fixed and the torque is changed from $5 \mathrm{Nm}$ to $10 \mathrm{Nm}$ at $\mathrm{t}=2.5 \mathrm{~s}$ )

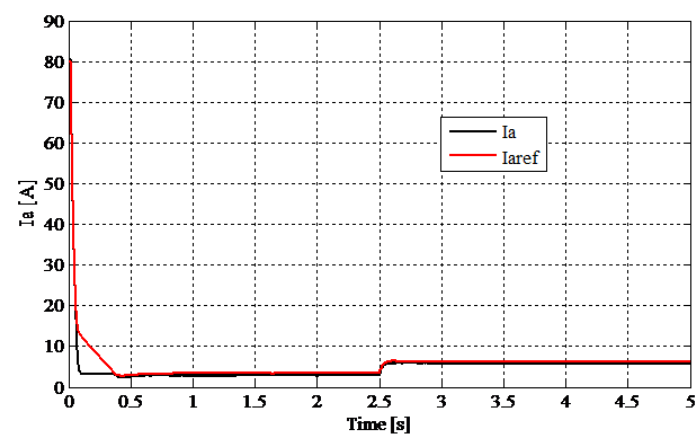

Fig. 12: Armature current and its reference (speed reference fixed and the torque is changed from $5 \mathrm{Nm}$ to $10 \mathrm{Nm}$ at $\mathrm{t}=2.5 \mathrm{~s}$ )

Explicitly, the use Petri nets controller instead of just a PI controller in our control strategy gives interesting results. On one hand, the armature current tracks perfectly its reference, and on the other hand the capacitor voltage is perfectly regulated, which ensures a safe converter operation and minimizes the losses in the system. This improves the quality of output energy and the lifetime of the DC motor. It is also noted that the proposed controller can be readily implemented in practice. As a future work, we are work-

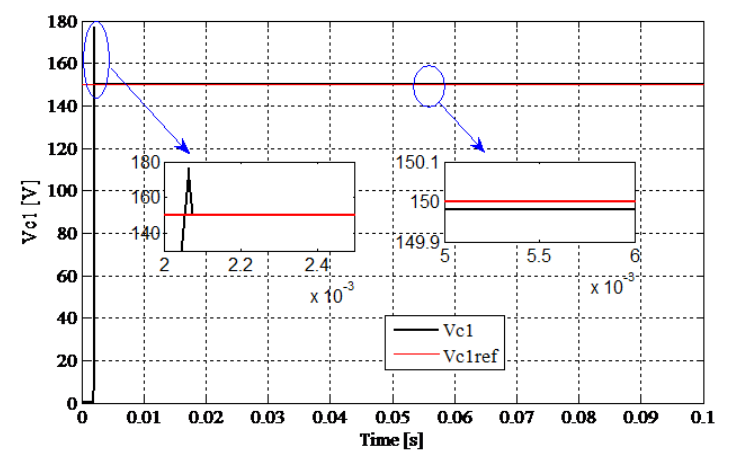

Fig. 13: Capacitor voltage

ing to develop our control method with a multi-cells chopper model more than two cells, which further improves the quality of the output energy.

\section{References}

[1] A.Z. Ahmad and M.N. Taib, "A study on the DC motor speed control by using back-EMF voltage", Asian Conference on Sensors (AsiaSense 2003), pp. 359- 364, 2003.

[2] M. Zeraoulia, M.E.H. Benbouzid and D. Diallo, "Electric motor drive selection issues for HEV propulsion systems: A comparative study,"IEEE Transactions on Vehicular Technology, vol. 55, no. 6, pp.1756-1764, 2006.

[3] S. Tharani, P. Palpandian and N. Gowthaman, "Speed control of a separately excited dc motor using optimization techniques," International Journal of Innovative Research in Computer and Communication Engineering, vol. 2, pp. 3924-3934, 2014.

[4] N. Jeddi, N. Ouasli, L. El Amraoui and F. Tadeo, "Speed control of a separately-excited DC motor powered by photovoltaic energy," IREC2015 - The Sixth International Renewable Energy Congress, pp. 1-6, 2015.

[5] R. Nagarajan, S. Sathishkumar, K. Balasubramani, C. Boobalan, S. Naveen and N. Sridhar, "Chopper fed speed control of DC motor using PI controller," IOSR Journal of Electrical and Electronics Engineering, vol.11, pp. 65-69, 2016.

[6] K. Shantanu and U. Chand bind, "Performance analysis of separately excited DC motor using PI and fuzzy logic controller," International Journal of Advanced Research in Electrical, Electronics and Instrumentation Engineering, vol.6, pp. 41094019, 2017.

[7] M. George "Speed control of separately excited DC motor," American Journal of Applied Science, vol.5, pp. 1546-9239, 2008.

[8] R. Abhinav and S. Sheel, "An adaptive, robust control of DC motor using fuzzy-PID controller,"2012 IEEE International Conference on Power Electronics, Drives and Energy Systems (PEDES), Bengaluru, India, pp. 1-5, 2012.

[9] V.R. Vadapalli, H.K. Kella, T.R. Sekhar, Y.D. Samson and N. Avinash, "Speed control of DCmotor using chopper", International Journal of Electrical and Electronics Research, vol. 3, pp. 
289- 295, 2015.

[10] R. Nagarajan, S. Sathishkumar, S. Deepika, G. Keerthana, J.K. Kiruthika and R. Nandhini, "Implementation of chopper fed speed control of separately excited DC motor using PI controller", International Journal of Engineering and Computer Science, vol. 6, pp. 20631-20633, 2017.

[11] K.S. Deshmukh and R.S. Hiware, "Speed control of separately excited DC motor using chopper," International Research Journal of Engineering and Technology, vol. 4, pp. 799-803, 2017.

[12] A. Harrouz, H. Becheri, I. Colak and K. Kayisli, "Backstepping control of a separately excited DC motor," Electrical Engineering, https://doi.org/10.1007/s00202-017-0592-5, 2017.

[13] G. Gateau, Contribution à la commande des convertisseurs statiques multicellulaires: Commande non linéaire et commande floue, Ph.D. dissertation, INPT, French, 1997.

[14] 0. Tachon, Commande découplante linéaire des convertisseurs multicellulaires série, Ph.D. dissertation, INPT, French, 1998.

[15] T.A. Meynard, H. Foch, P. Thomas, J. Courault, R. Jakob and M. Nahrstaedt, "Multicell converters: basic concepts and industry applications", IEEE Transactions on Industrial Electronics, vol.49, pp. 955-964, 2002.

[16] S. Ben Said, K. Ben Saad and M. Benrejeb, "HIL simulation approach for a multicellular converter controlled by sliding mode," International Journal of Hydrogen Energy, vol. 42, pp. 12790-12796, 2017.

[17] R.K. Munje, M. R. Roda and B.E. Kushare, "Speed control of DC motor using PI and SMC", IEEE International Conference on Power and Energy, Singapore, pp. 945-950, 2010.

[18] P. M. Meshram and R. G. Kanojiya, "Tuning of PID controller using Ziegler-Nichols method for speed control of DC motor," IEEE-International Conference on Advances in Engineering, Science and Management (ICAESM -2012), Nagapattinam, Tamil Nadu, India, pp. 117-122, 2012.
[19] D.C. Chengaiah and K. Venkateswarlu, "Comparative study on DC motor speed control using various controllers", Global Journal of Researches in Engineering Electrical and Electronics Engineering, vol. 13, pp.19-22, 2013.

[20] C. Kumar, D. Tanti, "Speed control of separately excited D.C. motor," Second International Conference on Emerging Trends in Engineering and Management Research (ICETEMR-2017), Pune, India, pp. 29-39, 2017.

[21] R. David and H. Alla, Discrete, Continuous, and Hybrid Petri Nets, Springer, Berlin, Germany, 2005.

[22] B.C. Florea, D.A. Stoichescu and V. Stefanescu, "A Petri net approach to multicellular chopper control,"2011 IEEE 17th International Symposium for Design and Technology in Electronic Packaging (SIITME), Timisoara, pp. 227-230, 2011.

[23] B. Amghar, M. Darcherif and J.-P. Barbot. "Z(TN)-Observability and control of parallel multicell chopper using Petri nets," IET Power Electronics, vol. 6, no. 4, pp.710-720, April 2013.

[24] B.C. Florea, "Petri net modeling for hybrid systems control. Application for a multicellular converter," 2013 Eighth International Symposium on Advanced Topics in Electrical Engineering (ATEE), Bucharest, Romania, pp. 1-4, 2013.

[25] F. Salinas, M. Ghanes, J.P. Barbot, M.F. Escalante, and B. Amghar, "Modeling and control design based on petri nets for serial multicellular choppers," IEEE Transactions on Control Systems Technology, vol. 23, no. 1, January 2015.

[26] F. Salinas, M. A. González, M. F. Escalante and J. de León Morales, "Control design strategy for flying capacitor multilevel converters based on Petri nets," IEEE Transactions on Industrial Electronics, vol. 63, no. 3, pp. 1728-1736, 2016.

[27] K. Benmansour, Réalisation d'un banc d'essai pour la commande et l'observation des convertisseurs multicellulaires série: Approche hybride, Ph. D. Dissertation, Cergy Pontoise University, France, 2009. 